\title{
Biodecontamination of milk and dairy products by probiotics: Boon for bane
}

\author{
Razieh Sadat Mirmahdi ${ }^{1}$, Alaleh Zoghi ${ }^{2}$, Fatemeh Mohammadi ${ }^{1}$, Kianoush Khosravi-Darani ${ }^{2 *}$, Shima Jazaiery ${ }^{3}$, \\ Reza Mohammadi ${ }^{4}$, Yasir Rehman ${ }^{5}$
}

${ }^{1}$ Student Research Committee, Department of Food Science and Technology, National Nutrition and Food Technology Research Institute, Faculty of Nutrition Science and Food Technology, Shahid Beheshti University of Medical Sciences, Tehran, Iran; ${ }^{2}$ Department of Food Science and Technology, National Nutrition and Food Technology; ${ }^{3}$ Department of Nutrition, School of Public Health, Iran University of Medical Sciences, Tehran, Iran; ${ }^{4}$ Department of Food Science and Technology, School of Nutrition Sciences and Food Technology, Research Center for Environmental Determinants of Health (RCEDH), Health Institute, Kermanshah University of Medical Sciences, Kermanshah, Iran; ${ }^{5}$ Department of Life Sciences, School of Science, University of Management and Technology, Lahore, Pakistan

*Corresponding Author: Kianoush Khosravi-Darani, Prof. Food Biotechnology. Shahrake gharb, Farahzadi Blv., Hafesi St. No7, Tehran Iran, P. O. Box: 19395-4741, Tehran, Iran. Email: k.khosravi@sbmu.ac.ir and kiankh@yahoo.com

Received: 17 April 2021; Accepted: 31 May 2021; Published: 1 July 2021

(c) 2021 Codon Publications

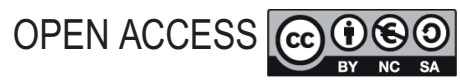

REVIEW ARTICLE

\begin{abstract}
In recent decades, "contamination of the environment, food, and feed by different contaminants such as heavy metals and toxins is increasing due to industrial life." Commercial milk and milk products can be contaminated with heavy metals and mycotoxins. Biosorption is a low-cost method and has good potential for decontamination. In dairy products, "various starters, especially probiotics, can be used as biosorbants, while microorganisms are able to bind to heavy metals and toxins and decrease their bioavailability and hazards in the human body." In this article, the key role of dairy starters and probiotics in the decontamination of toxins and heavy metals, and the best probiotics for decontamination of aflatoxins and heavy metals has been reviewed. After a quick glance at introducing dairy products and the main risks in association with the intake of some hazardous materials from dairy products, the application of biological systems is mentioned. Then, the article is focused on the role of beneficial microorganisms as the last chance to decrease the risk of exposure to toxins and heavy metals in dairy products. This review can be helpful for biotechnologists and scientists who have challenges about the existence of heavy metals and toxins in milk and dairy products, and help them to find the best method to decrease the content of the usual contaminants.
\end{abstract}

Keywords: aflatoxins; biosorption; decontamination; heavy metals; dairy products

\section{Introduction}

The World Health Organization (WHO) defines food safety as, "Approaches and methods for certifying the manufacture, maintenance, distribution and utilization of food happen in an assured system." However, some people defined safe food as food without any contamination (El Sheikha, 2015).
Heavy metals naturally exist in the environment. Industrial activities can increase their content in air and soil, leading to phytotoxicity of plants (Asati et al., 2016; Yang et al., 2018). Milk and dairy products have an important role in the human food chain, especially children's food; so, contamination of dairy products by toxins and heavy metals is one of the most important issues that can negatively impact consumers' health. Milk and dairy 
products can be contaminated with heavy metals under certain conditions through contamination of water and animal feed with environmental contaminants such as metal and cement smelters, sewage effluents, and industrial waste. Heavy metals' accumulation in milk can easily enter the human body and be dangerous for consumer's health (Abedi et al., 2020). Dairy product contamination (heavy metal and aflatoxin) is very common all over the world (Ziarati et al., 2018).

Heavy metals' toxicity occurs in levels of about 1.0-10 $\mathrm{mg} / \mathrm{L}$; however, lead and cadmium could have a toxic effect in 1-100 $\mu \mathrm{g} / \mathrm{L}$ (Alkorta et al., 2004). For example, different levels of exposure to cadmium could cause renal dysfunction, hepatic injury, and lung damage (Miura et al., 2017; Naidoo et al., 2019; Zhang et al., 2014). Arsenic poisoning can cause death through disorder in essential metabolic enzymes (Khairul et al., 2017). Maximum permissible limits of heavy metal contents in milk (considered by International Dairy Federation) are $2.6 \mu \mathrm{g} / \mathrm{kg}$ for cadmium, $10 \mu \mathrm{g} / \mathrm{kg}$ for Copper, $20 \mu \mathrm{g} / \mathrm{kg}$ for lead, and $328 \mu \mathrm{g} / \mathrm{kg}$ for zinc (Malhat et al., 2012).

Aflatoxins directly (through eating contaminated food) and indirectly (primary contaminated products such as milk of contaminated livestock) can enter into the human body by the use of contaminated dairy products. Aflatoxins can cause negative effects on human health, such as liver or kidney cancer and chronic intoxications (Karazhiyan et al., 2016). The most common aflatoxin in dairy products is aflatoxin $M_{1}\left(A_{F} M_{1}\right)$. AFM $M_{1}$ is a metabolite of aflatoxin $\mathrm{B}_{1}\left(\mathrm{AFB}_{1}\right)$ after ingestion of contaminated feed $\left(\mathrm{AFB}_{1}\right)$ by livestock. About 0.3 to $6.2 \%$ of $\mathrm{AFB}_{1}$ (Abdelmotilib et al., 2018) can be bio-transformed into $\mathrm{AFM}_{1}$ (4-hydroxy- $\mathrm{AFB}_{1}$ ) and can excrete into milk and urine (Iha et al., 2013; Karazhiyan et al., 2016). AFM is carcinogenic and toxicogenic, and can resist pasteurization and sterilization processes (Gonçalves et al., 2020). AFM 1 compared with $\mathrm{AFB}_{1}$ is approximately 10 times less mutagenic, genotoxic, and toxigenic. Its carcinogenic effects are displayed in different kinds of species (Elsanhoty et al., 2014). AFM 1 can also cause gene mutation, DNA damage, cell transformation in mammalian cells, and chromosomal anomalies. Food and Drug Administration (FDA) and the European Commission recommended that the maximum permissible limits of $\mathrm{AFM}_{1}$ in milk are $0.5 \mu \mathrm{g} / \mathrm{kg}$ and $0.05 \mu \mathrm{g} / \mathrm{kg}$, respectively (Commission, 2006; FDA, 2019)

It is reported that mycotoxins in milk and dairy products, which can be produced by different kinds of fungi are: Aflatoxins (by Aspergillus), Compactin (by Penicillium), Cyclopaldic acid (by Penicillium), and Patulin (by Penicillium) (El Sheikha, 2019).

Many reports have investigated regarding contamination of milk by heavy metals and toxins all over the world. According to Tables 1 and 2, which present some of the above reports, the amount of lead in Iraq, Brazil, China, Spain, and Italy was more than the maximum permissible

Table 1. Some important data about milk contamination to heavy metals (from 2014 to 2021).

\begin{tabular}{|c|c|c|c|}
\hline Country & Contamination & Concentration & Reference \\
\hline Egypt & $\begin{array}{l}\mathrm{Pb} \\
\mathrm{Cd}\end{array}$ & $\begin{array}{l}0.044-0.751 \mathrm{mg} / \mathrm{L} \\
0.008-0.179 \mathrm{mg} / \mathrm{L}\end{array}$ & Meshref et al., 2014 \\
\hline Serbia & $\begin{array}{l}\mathrm{Pb} \\
\mathrm{Cd}\end{array}$ & $\begin{array}{l}54.3-95.2 \mathrm{lg} / \mathrm{kg} \\
2.13-4.82 \mathrm{lg} / \mathrm{kg}\end{array}$ & Suturović et al., 2014 \\
\hline Iraq & $\mathrm{Pb}$ & $32 \mu \mathrm{g} / \mathrm{L}$ & Alani and Al-Azzawi, 2015 \\
\hline Pakistan & $\begin{array}{l}\mathrm{Pb} \\
\mathrm{Cd}\end{array}$ & $\begin{array}{l}0.014 \mathrm{mg} / \mathrm{Kg} \\
0.001 \mathrm{mg} / \mathrm{Kg}\end{array}$ & Ismail et al., 2015 \\
\hline Bangladesh & $\begin{array}{l}\mathrm{Pb} \\
\mathrm{Cd}\end{array}$ & $\begin{array}{c}0.2 \mathrm{mg} / \mathrm{L} \\
0.073 \mathrm{mg} / \mathrm{L}\end{array}$ & Muhib et al., 2016 \\
\hline Iran & $\begin{array}{l}\mathrm{Pb} \\
\mathrm{Cd}\end{array}$ & $\begin{array}{l}14.0 \mu \mathrm{gg} / \mathrm{kg} \\
1.11 \mu \mathrm{g} / \mathrm{kg}\end{array}$ & Shahbazi et al., 2016 \\
\hline Brazil & $\mathrm{Pb}$ & $2.12-37.36 \mu \mathrm{g} / \mathrm{L}$ & de Oliveira et al., 2017 \\
\hline Mexico & $\begin{array}{l}\mathrm{Pb} \\
\mathrm{As}\end{array}$ & $\begin{array}{l}0.03 \mathrm{mg} / \mathrm{Kg} \\
0.12 \mathrm{mg} / \mathrm{Kg}\end{array}$ & Castro-González et al., 2018 \\
\hline Poland & $\begin{array}{l}\mathrm{Pb} \\
\mathrm{Cd}\end{array}$ & $\begin{array}{l}5.24 \mu \mathrm{g} / \mathrm{L} \\
0.15 \mu \mathrm{g} / \mathrm{L}\end{array}$ & Halagarda et al., 2018 \\
\hline Turkey & $\begin{array}{l}\mathrm{Pb} \\
\mathrm{Cd} \\
\mathrm{As}\end{array}$ & $\begin{array}{c}0.0055 \mathrm{mg} / \mathrm{L} \\
0.088 \mathrm{mg} / \mathrm{L} \\
0.002 \mathrm{mg} / \mathrm{L}\end{array}$ & Seğmenoğlu and Baydan, 2021 \\
\hline
\end{tabular}

As: Arsenic, Cd: Cadmium, Pb: Lead 
Table 2. Some important data about milk contamination to mycotoxins in world from 2014 to 2021.

\begin{tabular}{|c|c|c|c|}
\hline Country & Contamination & Concentration & Reference \\
\hline Croatia & $\mathrm{AFM}_{1}$ & $0.003-1.135 \mu \mathrm{g} / \mathrm{L}$ & Bilandžić et al., 2014 \\
\hline China & $\begin{array}{c}\mathrm{AFM}_{1} \\
\mathrm{OA} \\
\mathrm{ZEA} \\
\alpha-\mathrm{ZEA}\end{array}$ & $\begin{array}{l}80.4 \mathrm{ng} / \mathrm{kg} \\
56.7 \mathrm{ng} / \mathrm{kg} \\
14.9 \mathrm{ng} / \mathrm{kg} \\
24.3 \mathrm{ng} / \mathrm{kg}\end{array}$ & Huang et al., 2014 \\
\hline Serbia & $\mathrm{AFM}_{1}$ & $0.01-1.2 \mu \mathrm{g} / \mathrm{kg}$ & Kos et al., 2014 \\
\hline Iran & $\mathrm{AFM}_{1}$ & $>0.05 \mu \mathrm{g} / \mathrm{L}$ & Fallah et al., 2015 \\
\hline Macedonia & $\mathrm{AFM}_{1}$ & $408.1 \mathrm{ng} / \mathrm{L}$ & Dimitrieska-Stojković et al., 2016 \\
\hline Pakistan & $\mathrm{AFM}_{1}$ & $>2610 \mathrm{ng} / \mathrm{L}$ & Aslam et al., 2016 \\
\hline Argentina & $\mathrm{AFM}_{1}$ & $293 \mathrm{ng} / \mathrm{L}$ & Michlig et al., 2016 \\
\hline Bosnia and Herzegovina & $\mathrm{AFM}_{1}$ & $60 \mathrm{ng} / \mathrm{L}$ & Bilandžić et al., 2016 \\
\hline Italy & $\mathrm{AFM}_{1}$ & $52 \mathrm{ng} / \mathrm{L}$ & De Roma et al., 2017 \\
\hline Tanzania & $\mathrm{AFM}_{1}$ & $0.627 \mathrm{ng} / \mathrm{mL}$ & Karczmarczyk et al., 2017 \\
\hline Malaysia & $\mathrm{AFM}_{1}$ & $144 \mathrm{ng} / \mathrm{L}$ & Shuib et al., 2017 \\
\hline Kosovo & $\mathrm{AFM}_{1}$ & $83 \mathrm{ng} / \mathrm{L}$ & Camaj et al., 2018 \\
\hline El Salvador & $\mathrm{AFM}_{1}$ & Approximately $100 \mathrm{ng} / \mathrm{L}$ & Peña-Rodas et al., 2018 \\
\hline Turkey & $\mathrm{AFM}_{1}$ & $78.69 \mathrm{ng} / \mathrm{L}$ & Eker et al., 2019 \\
\hline Ethiopia & $\mathrm{AFM}_{1}$ & 207 ng/L & Zakaria et al., 2019 \\
\hline Kenya & $\mathrm{AFM}_{1}$ & $4563 \mathrm{ng} / \mathrm{L}$ & Kuboka et al., 2019 \\
\hline Brazil & $\mathrm{AFM}_{1}$ & $45.18 \mathrm{ng} / \mathrm{L}$ & Venâncio et al., 2019 \\
\hline Ecuador & $\mathrm{AFM}_{1}$ & $0.0774 \mu \mathrm{g} / \mathrm{kg}$ & Puga-Torres et al., 2020 \\
\hline Spain & $\mathrm{AFM}_{1}$ & $0.009-1.36 \mu \mathrm{g} / \mathrm{kg}$ & Rodríguez-Blanco et al., 2020 \\
\hline India & $\mathrm{AFM}_{1}$ & $1116 \mathrm{ng} / \mathrm{L}$ & Sharma et al., 2020 \\
\hline Morocco & $\mathrm{AFM}_{1}$ & $4.46 \pm 14.09 \mathrm{ng} / \mathrm{L}$ & Mannani et al., 2021 \\
\hline Malawi & $\mathrm{AFM}_{1}$ & $0.551 \mu \mathrm{g} / \mathrm{L}$ & Njombwa et al., 2021 \\
\hline Spain & $\begin{array}{l}\mathrm{AFM}_{1} \\
\mathrm{AFB}_{1}\end{array}$ & $\begin{array}{l}12.6 \mathrm{ng} / \mathrm{kg} \\
0.61 \mu \mathrm{\mu} / \mathrm{kg}\end{array}$ & Bervis et al., 2021 \\
\hline
\end{tabular}

AFM 1 : Aflatoxin $\mathrm{M}_{1} \mathrm{AFB}_{1}$ : Aflatoxin $\mathrm{B}_{1}, \mathrm{OA}$ : Ochratoxin A, ZEA: Zearalenone, $\alpha$-ZEA: $\alpha$-zearalenone.

limits. Also, AFM in China and India, and cadmium in Poland and Spain, were higher than permissible limits. This information confirms the importance of decontamination in milk and dairy products.

There are different methods for the decontamination of dairy products, such as physical, chemical (reverse osmosis, ion exchange, freeze concentration, and evaporation) (Patterson and Minear, 2013), and biological methods (using different biomaterials such as bacteria and yeasts biomass, plants, and seaweeds) (Abdelmotilib et al., 2018; Hashim and Chu, 2004; Hayat et al., 2017; Satyapal et al., 2016; Sulaymon et al., 2013; Vishnoi et al., 2014). Adsorption is one of the most important decontamination strategies in dairy products (Giovati et al., 2015; Massoud et al., 2019; Milanowski et al., 2017; Porova et al., 2014). There are different biosorbents, such as "algae, plants, yeasts, fungi, and bacteria," for the bioremoval of toxins and metals in fermented dairy products (e.g., kefir, kumis, yogurt, and doogh). Probiotic bacteria can also be used for this purpose. Fermented dairy products are very popular, and they have a perfect taste (El Sheikha et al., 2018; Yerlikaya, 2014). Probiotics can reduce contamination (heavy metals and aflatoxins) in fermented dairy products (Zoghi et al., 2014). They are widely used for bioremoval of toxins (Massoud et al., 2018; Zoghi et al., 2017, 2019) as well as heavy metals (arsenic, mercury, lead, and cadmium) (Hadiani et al., 2018, 2019; Khosravi-Darani et al., 2019), heterocyclic aromatic amines (Khosravi-Darani et al., 2019; Sarlak, 2020), and even pesticides (Wochner et al., 2018).

In this article, reports about the influence of adding starters and probiotics into the formulation of dairy products on the bioremoval of contaminations such as toxins and heavy metals are reviewed.

\section{Starters and Probiotics in Dairy Products}

Food fermentation by microorganisms is one of the most economic and widely practiced methods for improving 
texture, flavor, and functionality, and also for enhancing the shelf life of food products (Ray et al., 2014; Salque et al., 2013). The fermentation process can be carried out with starter cultures to certify consistency in commercial products by using familiar microorganisms with favorable traits, such as a high amount of acidification via the manufacture of lactic acid and/or the sprinkling of secondary metabolites in the product matrix (Ryan et al., 2015). Different starters have been used for producing various dairy products all around the world. Some of these products and their starters are mentioned in Table 3.

Table 3. Some fermented dairy products and related starters.

\begin{tabular}{|c|c|c|c|}
\hline $\begin{array}{l}\text { Fermented dairy } \\
\text { products }\end{array}$ & Country/Region of origin & Starters & Reference \\
\hline Acidophilus milk & - & $\begin{array}{l}\text { Lactobacillus acidophilus, Lactobacillus casei, Bifidobacterium } \\
\text { bifidum, Lactobacillus bulgaricus, Streptococcus thermophilus }\end{array}$ & $\begin{array}{l}\text { Raftaniamiri et al., } \\
2010\end{array}$ \\
\hline Buttermilk & Egypt and Ethiopia & $\begin{array}{l}\text { (cultured buttermilk) Lactic acid bacteria (e.g., Lactococcus, } \\
\text { Lactobacillus, Streptococcus, and Leuconostocs) }\end{array}$ & $\begin{array}{l}\text { El Sheikha and } \\
\text { Montet, 2014; Kumar } \\
\text { et al., } 2015\end{array}$ \\
\hline Cheese & - & $\begin{array}{l}\text { (cheddar cheese) Lactic acid bacteria starter culture } \\
\text { (Lactococcus lactis ssp. lactis, Lactococcus lactis ssp. } \\
\text { cremoris, and Streptococcus salivarius spp. thermophilus) }\end{array}$ & $\begin{array}{l}\text { Ferreira and Viljoen, } \\
2003\end{array}$ \\
\hline Matzoon & Armenia & Lactic acid bacteria & $\begin{array}{l}\text { Macori and Cotter, } \\
2018\end{array}$ \\
\hline Leben & Arab World & $\begin{array}{l}\text { (Leben from camel milk) Lactococcus lactis, Lactobacillus } \\
\text { pentosus, Lactobacillus plantarum, Lactobacillus brevis, and } \\
\text { Pediococcus pentosaceus }\end{array}$ & Fguiri et al., 2013 \\
\hline Kishk & Arab World & Freeze-dried yogurt starter culture & Tamime et al., 2000 \\
\hline Kumis & $\begin{array}{l}\text { Central Asia } \\
\text { Turkic countries } \\
\text { Central Asia }\end{array}$ & $\begin{array}{l}\text { Lactococcus lactis subsp. lactis, Streptococcus thermophilus, } \\
\text { Lactobacillus delbrueckii subsp. bulgaricus, Lactobacillus } \\
\text { helveticus, Lactobacillus casei subsp. Pseudoplantarum, and } \\
\text { Lactobacillus brevis } \\
\text { Kluyveromyces marxianus var. lactis, Saccharomyces } \\
\text { cerevisiae, Candida inconspicua, and Candida maris }\end{array}$ & Simova et al., 2002 \\
\hline Ymer & Denmark & $\begin{array}{l}\text { Streptococcus lactis, Streptococcus diacetilaclis., } \\
\text { Streptococcus cremoris, and Leuconostoc citrovorum }\end{array}$ & Poulsen, 1970 \\
\hline Kefir & $\begin{array}{l}\text { Estonia, Hungary, Greece, Latvia, } \\
\text { Romania, Slovakia, Bosnia and } \\
\text { Herzegovina }\end{array}$ & $\begin{array}{l}\text { Lactobacilli } \\
\text { Lactococcus } \\
\text { Acetic acid bacteria } \\
\text { and yeast }\end{array}$ & Garrote et al., 2001 \\
\hline Dahi & India & Lactobacillus case or Lactobacillus acidophilus & Yadav et al., 2005 \\
\hline Mishti doi & India & $\begin{array}{l}\text { Streptococcus salivarius ssp. Thermophiles, Lactobacillus } \\
\text { acidophilus, Lactobacillus delbrueckii ssp. bulgaricus, } \\
\text { Lactobacillus acidophilus, Lactococcus lactis ssp. lactis, } \\
\text { Saccharomyces cerevisiae }\end{array}$ & Gupta et al., 2000 \\
\hline Matsoni & Georgia & $\begin{array}{l}\text { Lactobacillus Streptococcus, Kluyveromyces marxianus, } \\
\text { Candida famata, Saccharomyces cerevisiae, Lodderomyces } \\
\text { elongisporus, Kluyveromyces lactis }\end{array}$ & Bokulich et al., 2015 \\
\hline Wara & Africa & $\begin{array}{l}\text { Lactobacillus sp., Leuconostoc sp., Pediococuus sp., } \\
\text { Lactococcus sp., yeasts }\end{array}$ & $\begin{array}{l}\text { El Sheikha and } \\
\text { Montet, } 2014\end{array}$ \\
\hline Biruni & Sudan & Lactic acid bacteria & $\begin{array}{l}\text { El Sheikha and } \\
\text { Montet, } 2014\end{array}$ \\
\hline Mish & Sudan and Egypt & Lactic acid bacteria & $\begin{array}{l}\text { El Sheikha and } \\
\text { Montet, } 2014\end{array}$ \\
\hline Rob & Sudan & Lactic acid bacteria & $\begin{array}{l}\text { El Sheikha and } \\
\text { Montet, } 2014\end{array}$ \\
\hline Doogh & Iran & $\begin{array}{l}\text { Lactobacillus acidophilus, Lactobacillus rhamnosus, } \\
\text { Lactobacillus casei, Bifidobacterium lactis }\end{array}$ & Sarlak et al., 2017 \\
\hline Yogurt & Serbia & Streptococcus thermophilus and Lactobacillus bulgaricus & $\begin{array}{l}\text { Elsanhoty et al., } \\
2014\end{array}$ \\
\hline Clabber & United States & Starters like Kefir & Dyomina et al., 2017 \\
\hline
\end{tabular}


FAO (2001) defined probiotics as, "viable microorganisms, that while ingested in sufficient amounts, exert health benefits on the host (FAO/WHO, 2001)." The main beneficial effects of probiotics on human health include mucosal immunity support, decreasing lactose intolerance, preventing respiratory infections or diarrheas, feasible hypocholesterolemia effects, prevention of intestinal pathogens, inhibition of colon cancer or inflammatory bowel disease (Sanders et al., 2014; Yu et al., 2015).

The application of microorganisms, especially probiotics, recently has been investigated for their potential to heavy metals and aflatoxins reduction (Zoghi et al., 2014). Most species known as probiotic bacteria are Bifidobacterium (B.), Lactobacillus (L.), Bacillus, and yeast Saccharomyces (S.) cerevisiae, and some strains of Escherichia (E.) coli. A practical taxonomy of nonpathogenic, fermentative, and nontoxigenic probiotic bacteria is lactic acid bacteria (LAB), which are used widely in food industries (Zoghi et al., 2017). LAB usually have gram-positive cell walls, and peptidoglycan is their main cell wall structural component; teichoic acid, lipoteichoic acid, some neutral polysaccharides, and a proteinous S-layer are their minor components (Zoghi et al., 2014).

\section{Toxins' Bioremoval in Milk and Dairy Products}

In recent decades, several scientific studies have been done regarding decontamination in dairy products, especially the biological decontamination method. Some of these researches are mentioned in Table 4.

El Khoury et al. (2011) investigated the application of LAB including L. bulgaricus and Streptococcus thermophiles on the reduction of AFM. They showed that using $\mathrm{LAB}$ is a potential method to decrease $\mathrm{AFM}_{1}$ with the higher efficiency of $L$. bulgaricus compared to Streptococcus thermophiles. They also mentioned that the level of $A F M_{1}$, which is bound by LAB, enhanced with increasing the time of inoculation (El Khoury et al., 2011). The binding ability of yogurt cultures was different. It is suggested that the difference in the binding ability of LAB is attributed to the difference in their cell-wall structure (Sarimehmetoğlu and Küplülü, 2004).

In addition to LAB, using S. cerevisiae is considered as an effective way for microbial detoxification (Karazhiyan et al., 2016). A systematic review by Campagnollo et al. (2020) focused on parameters influencing the binding process of $\mathrm{AFM}_{1}$ by yeast. The overall binding level of yeast was reported as $52.05 \%$, in which the lowest binding capacity was related to the yeast extract peptone and the highest binding was associated with the ruminal fluid. Also, different factors, including temperature, yeast, $\mathrm{pH}$, and the type of aflatoxin, have been mentioned as the major parameters in the process of decontamination (Campagnollo et al., 2020). Moreover, the effect of different treated S. cerevisiae, including heat, acid, and ultrasound treated, on the binding with $\mathrm{AFM}_{1}$ was assessed by Karazhiyan et al. (2016). Among all treated yeasts, acid treatment had the most positive impact on yeast cells for improving their binding ability to aflatoxins which can be attributed to the release of monomers from polysaccharides under acidic conditions and their further changes into aldehydes after breaking down of glycosides linkages. After acid treatment, heat-treated yeasts showed the highest binding ability due to protein denaturation and Maillard reaction product formation, which caused an increase in the permeability of cell walls. Comparison between viable and unviable yeasts (heat, acid, and ultrasound treated) exhibited higher efficiency of unviable cells, which indicates that such treatments increase the binding capacity of yeasts (Karazhiyan et al., 2016).

In a study performed by Taheur et al. (2017), a novel strategy for the reduction of mycotoxins using kefir grains was examined. The results showed that kefir microorganism grains could adsorb 82 to $100 \%$ of $\mathrm{AFB}_{1}$, zearalenone, and ochratoxin A after cultivation in milk. The main strains that were able to adsorb mycotoxins were L. kefiri, Kazachstania servazzii, and Acetobacter syzygii. The L. kefiri KFLM3 was found to be the most active strain with an adsorption rate of 80 to $100 \%$ of the mycotoxins, and K. servazzii KFGY7 was found to retain higher mycotoxin than others after the desorption experiments. As a result, kefir consumption can assist in diminishing gastrointestinal absorption of mycotoxins and their toxic effects (Taheur et al., 2017).

\section{Heavy Metals' Bioremoval in Milk and Dairy Products}

In Table 5, investigations regarding heavy metal bioremoval in milk and dairy products are illustrated.

In two different studies by Massoud et al. (2019, 2020a), application of S. cerevisiae to reduce the concentrations of lead and cadmium in milk was examined. The optimization process was also performed considering three factors including contact time, concentrations of biomass, and initial content of heavy metals (Massoud et al., 2019, 2020a). Generally, the rate of removal of heavy metals increased with an increase in the biomass, contact time, and concentration of heavy metals. They concluded that optimized conditions for lead removal were obtained after 4 days (at the end of storage time) with the content of $22 \times 10^{8} \mathrm{CFU} / \mathrm{mL}$ of yeast and $70 \mu \mathrm{g} / \mathrm{L}$ of lead in milk (Massoud et al., 2019). Similarly, the optimized process for cadmium bioremoval was achieved after 4 days with $80 \mu \mathrm{g} / \mathrm{L}$ of cadmium and $30 \times 10^{8} \mathrm{CFU} / \mathrm{mL}$ of $S$. cerevisiae 
Table 4. Aflatoxin decontamination in milk and dairy products.

\begin{tabular}{|c|c|c|c|c|c|}
\hline Product & Microorganism & Removal w/w\% & Contaminant & Conditions & Reference \\
\hline Milk & $\begin{array}{l}\text { Lactobacillus rhamnosus } \\
\text { (milk whey medium) }\end{array}$ & $46.0 \%$ & $\mathrm{AFB}_{1}$ & $\begin{array}{l}\text { Optimal condition: } \\
60 \text { min in } \mathrm{pH} 3.0\end{array}$ & Bovo et al., 2014 \\
\hline Milk & $\begin{array}{l}\text { Kefir starters } \\
\text { 1. L. acidophilus, Bifidobacterium, } \\
\text { \& Streptococcus thermophiles } \\
\text { (thermophilic lactic culture) } \\
\text { 2. Lactococcus lactis subsp. } \\
\text { cremoris, Leuconostoc, } \\
\text { Lactococcus lactis subsp. } \\
\text { lactis biovar diacetylactis, } \\
\text { Lactococcus lactis, subsp. lactis, } \\
\text { 3. Debaryomyces hansenii, } \\
\text { Kluyveromyces marxianus subsp. } \\
\text { marxianus., yeast pool, Lactic } \\
\text { acid bacteria pool }\end{array}$ & $\begin{array}{l}\text { Full kefir starters } \\
11.67-34.66 \% \\
\text { Yeast pool } \\
65.33-68.89 \% \\
\text { LAB pool } \\
65 \%\end{array}$ & $\mathrm{AFM}_{1}$ & $\begin{array}{l}\text { Toxin } \\
\text { Concentration: } \\
\text { 150, } 200 \text {, and } \\
250 \mathrm{ng} / \mathrm{L} \\
\text { Temperature: } 4^{\circ} \mathrm{C} \\
\text { Time: } 7 \text { days }\end{array}$ & $\begin{array}{l}\text { Kamyar and } \\
\text { Movassaghghazani, } \\
2017\end{array}$ \\
\hline Milk & Lactobacillus helveticus & $85 \%$ & $\mathrm{AFM}_{1}$ & Time: $60 \mathrm{~min}$ & Ismail et al., 2017 \\
\hline Milk & Saccharomyces cerevisiae & $81.3 \%$ & $\mathrm{AFM}_{1}$ & Time: $48 \mathrm{~h}$ & Foroughi et al., 2018 \\
\hline Yogurt & $\begin{array}{l}\text { A: S. thermophilus \& L. bulgaricus } \\
\text { B: } 50 \% \text { S. thermophilus \& } L \text {. } \\
\text { bulgaricus } \\
50 \% \text { L. planetarum } \\
\text { C: } 50 \% \text { S. thermophilus and L. } \\
\text { bulgaricus, } 50 \% \text { L. acidophilus }\end{array}$ & $\begin{array}{l}\text { Treatment B: } \\
\text { Highest reduction } \\
31.5-87.8 \%\end{array}$ & $\mathrm{AFM}_{1}$ & $\begin{array}{l}\text { Temperature: } \\
5^{\circ} \mathrm{C} \text {, Storage time: } \\
1,3,5 \text {, and } 7 \text { days }\end{array}$ & $\begin{array}{l}\text { Elsanhoty et al., } \\
2014\end{array}$ \\
\hline Yoghurt & $\begin{array}{l}\text { Lactobacillus } \\
\text { acidophilus }\end{array}$ & $90 \%$ & $\mathrm{AFM}_{1}$ & $\begin{array}{l}10^{8} \mathrm{CFU} / \\
\mathrm{mL}, \text { Initial } \\
\text { concentration of } \\
\text { AFM }_{1}: 0.1,0.5 \\
0.75 \mu \mathrm{g} / \mathrm{L}\end{array}$ & Adibpour et al., 2016 \\
\hline Yoghurt & Saccharomyces cerevisiae & $76.46 \%$ & $\mathrm{AFM}_{1}$ & $\begin{array}{l}\text { Aflatoxin } \mathrm{M}_{1}, 100 \text {, } \\
500 \text {, and } 750 \mathrm{~g} / \\
\mathrm{M}_{\mathrm{l}} \text {, in } 1,7,14, \\
\text { and } 21 \text { days, } \\
\text { yeast treatments: } \\
\text { heat, acid, and } \\
\text { ultrasound }\end{array}$ & $\begin{array}{l}\text { Karazhiyan et al., } \\
2016\end{array}$ \\
\hline Yoghurt & $\begin{array}{l}\text { Lactobacillus plantarum, } \\
\text { Bifidobacterium animalis, } \\
\text { Bifidobacterium bifidum }\end{array}$ & $\begin{array}{l}\text { Yogurt starters } \\
\text { and B. bifidum, } \\
\text { B. animalis ( } 60.8 \%) \text {, } \\
\text { Yogurt starters and } \\
\text { L. plantarum, } \\
\text { B. Bifidum } 55.1 \%)\end{array}$ & $\mathrm{AFM}_{1}$ & $\begin{array}{l}\text { Storage time: } \\
1 \text { or } 10 \text { days }\end{array}$ & Sevim et al., 2019 \\
\hline Yogurt & $\begin{array}{l}\text { L. plantarum, } B \text {. animalis, \& } B \text {. } \\
\text { bifidum, L. plantarum }\end{array}$ & $49-60 \%$ & $\mathrm{AFM}_{1}$ & $\begin{array}{l}\text { Contact time: } \\
4 \mathrm{~h} \text { Temperature: } \\
42^{\circ} \mathrm{C}\end{array}$ & Sevim et al., 2019 \\
\hline Kefir & Lactobacillus casei \& kefir starter & $88.17 \%$ & $\mathrm{AFM}_{1}$ & $\begin{array}{l}\text { Aflatoxin } \mathrm{M}_{1} 500 \\
\text { pg, Kefir starters } \\
2,4,6,8,10 \% \text {, } \\
\text { L. casei: } 0.1,0.3 \text {, } \\
0.5,0.7,0.9 \% \\
\text { in } 48 \mathrm{~h}\end{array}$ & Sani et al., 2014 \\
\hline Kefir & Kefir-grains & $96.8 \%$ & $\mathrm{AFG}_{1}$ & $\begin{array}{l}\text { Toxin } \\
\text { concentration } 5 \text {, } \\
10,15,20,25 \\
\text { ng/g, Kefir grain: } 5 \text {, } \\
10,20,10,25 \% \text {, } \\
\text { in } 0,2,4,6,8 \mathrm{~h}, \\
\text { at } 20,30,40,50 \text {, } \\
60^{\circ} \mathrm{C}\end{array}$ & Ansari et al., 2015 \\
\hline
\end{tabular}


Table 4. Continued

\begin{tabular}{|c|c|c|c|c|c|}
\hline Product & Microorganism & Removal w/w\% & Contaminant & Conditions & Reference \\
\hline Kefir & $\begin{array}{l}\text { Kefir grains: } \\
\text { Lactobacillus kefiri, Kazachstania } \\
\text { servazzii, Acetobacter syzygii }\end{array}$ & $82-100 \%$ & $\begin{array}{l}\mathrm{AFB}_{1}, \mathrm{ZEA}, \\
\mathrm{OA}\end{array}$ & $\begin{array}{l}1 \mu \mathrm{g} / \mathrm{Ml} \\
\text { mycotoxin, Kefir } \\
\text { grains } 10 \% \text { w/v in } \\
24 \text { at } 25^{\circ} \mathrm{C}\end{array}$ & Taheur et al., 2017 \\
\hline $\begin{array}{l}\text { UHT skim } \\
\text { milk }\end{array}$ & $\begin{array}{l}\text { Lactic acid bacteria } \\
\text { (Lactobacillus rhamnosus, } \\
\text { Lactobacillus delbrueckii spp. } \\
\text { Bulgaricus, Bifidobacterium } \\
\text { lactis), Saccharomyces cerevisiae }\end{array}$ & $\begin{array}{l}\text { LAB pool (30 min): } \\
11.5 \pm 2.3 \% \text { LAB ( } 60 \\
\text { min): } 11.7 \pm 4.4 \% \\
\text { Saccharomyces: ( } 30 \\
\text { min), } 90.3 \pm 0.3 \%, \\
\text { Saccharomyces: } 60 \\
\text { min, } 92.7 \pm 0.7 \%\end{array}$ & $\mathrm{AFM}_{1}$ & $\begin{array}{l}0.5 \mathrm{ng} A \mathrm{AFM}_{1} \mathrm{~mL}^{-1} \text {, } \\
\text { LAB pool: } \\
10^{10} \text { cells } \mathrm{mL}^{-1} \\
\text { Yeast: } \\
10^{9} \text { cells } \mathrm{mL}^{-1} \\
\text { Contact time: } \\
30 \text { min or } 60 \text { min }\end{array}$ & Corassin et al., 2013 \\
\hline $\begin{array}{l}\text { Fermented } \\
\text { milk drink }\end{array}$ & Lactobacillus casei Shirota & $\begin{array}{l}\text { AFB }_{1} \text {-lys reduction: } \\
82.37 \%\end{array}$ & $\begin{array}{l}\text { Serum } \mathrm{AFB}_{1}- \\
\text { lysine adduct }\end{array}$ & $\begin{array}{l}\text { 4-week } \\
\text { intervention } \\
\text { phases, (A): } \\
\text { probiotic drinks } 2 \\
\text { twice a day } \\
\text { (B): placebo for } 6 \text {, } \\
8 \text {, or } 10 \text { weeks }\end{array}$ & $\begin{array}{l}\text { Redzwan et al., } \\
2016\end{array}$ \\
\hline Doogh & $\begin{array}{l}\text { Lactobacillus acidophilus, } \\
\text { Lactobacillus rhamnosus, } \\
\text { Lactobacillus casei, , } \\
\text { Bifidobacterium lactis }\end{array}$ & $\begin{array}{l}\text { Day } 28, \text { Lactobacillus } \\
\text { acidophilus: } 98.8 \pm \\
1.3 \%\end{array}$ & $\mathrm{AFM}_{1}$ & $\begin{array}{l}0.500 \mathrm{ppb} \text { toxin, } \\
1,14 \text {, or } 28 \\
\text { days at } 5^{\circ} \mathrm{C}, \mathrm{L} \text {. } \\
\text { acidophilus } 9 \text { log } \\
\text { cfu/mL }\end{array}$ & Sarlak et al., 2017 \\
\hline $\begin{array}{l}\text { Ergo } \\
\text { fermented } \\
\text { milk }\end{array}$ & $\begin{array}{l}\text { L. plantarum } \\
\text { Lactobacillus acidophilus, } \\
\text { Lactobacillus brevis, Lactobacillus } \\
\text { casei subsp. casei, Lactobacillus } \\
\text { helveticus, Streptococcus } \\
\text { faecalis, Streptococcus } \\
\text { thermophiles, Leuconostoc } \\
\text { mesenteroides, subsp. cremoris }\end{array}$ & $\begin{array}{l}57.33 \% \\
54.04 \%\end{array}$ & $\mathrm{AFM}_{1}$ & $\begin{array}{l}\text { Time: } \\
1-5 \text { days } \\
\text { Temperature: } \\
25^{\circ} \mathrm{C}\end{array}$ & $\begin{array}{l}\text { Shigute and Washe, } \\
2018\end{array}$ \\
\hline
\end{tabular}

AFM $_{1}$ : Aflatoxin $M_{1}, A_{1}$ : Aflatoxin $B_{1}, O A$ : Ochratoxin A, ZEA: Zearalenone, AFG $:$ Aflatoxin $G_{1}$.

Table 5. Heavy metals decontamination in milk and dairy products.

\begin{tabular}{|c|c|c|c|c|c|}
\hline Product & Microorganism & Contaminant & Removal\% W/W & Conditions & Reference \\
\hline Milk & $\begin{array}{l}\text { Saccharomyces } \\
\text { cerevisiae }\end{array}$ & $\mathrm{Pb}$ & $70 \%$ & $\begin{array}{l}\text { Opt. at } 22 \times 10^{8} \mathrm{CFU} \text { inoculation of yeast, } \\
\text { Lead content } 70 \mu \mathrm{g} / \mathrm{l}\end{array}$ & $\begin{array}{l}\text { Massoud et al., } \\
2019\end{array}$ \\
\hline Kefir & $\begin{array}{l}\text { Lactococcus lactis, } \\
\text { Kluyveromyces } \\
\text { marxianus, } \\
\text { co-culture }\end{array}$ & $\begin{array}{l}\mathrm{Ni}, \\
\mathrm{Cu}, \\
\mathrm{Cd}, \\
\mathrm{Pb} \\
\mathrm{Fe}\end{array}$ & $\begin{array}{l}81.53 \%, 73.45 \% \\
79.48 \%, 68.53 \% \\
58.17 \%\end{array}$ & Time: 10 days & $\begin{array}{l}\text { Cherni et al., } \\
2020\end{array}$ \\
\hline Milk & $\begin{array}{l}\text { Saccharomyces } \\
\text { cerevisiae }\end{array}$ & $\mathrm{Cd}$ & $70 \%$ & $\begin{array}{l}\text { Cadmium content in milk } 80 \mu \mathrm{g} / \mathrm{L} \text {, } \\
30 \times 10^{8} \mathrm{CFU} \text { Saccharomyces cerevisiae, } \\
\text { storage time the } 4 \text { th day, }\end{array}$ & $\begin{array}{l}\text { Masoud et al., } \\
2020\end{array}$ \\
\hline Milk & $\begin{array}{l}\text { Lactobacillus } \\
\text { acidophilus }\end{array}$ & $\begin{array}{l}\mathrm{Pb} \\
\mathrm{Cd}\end{array}$ & $\begin{array}{l}80 \% \\
75 \%\end{array}$ & $\begin{array}{l}1 \times 10^{12} \mathrm{CFU} \text { of } L \text {. acidophilus, in } 4 \text { days } \\
\text { with the initial pollution of } 100 \mu \mathrm{g} / \mathrm{L} \text {. }\end{array}$ & $\begin{array}{l}\text { Massoud et al., } \\
2020 \mathrm{~b}\end{array}$ \\
\hline Milk & $\begin{array}{l}\text { Saccharomyces } \\
\text { cerevisiae }\end{array}$ & $\mathrm{Hg}$ & $70 \%$ & $\begin{array}{l}\text { Contact time: } 30 \text { days, initial } \\
\text { concentration of } \mathrm{Hg}: 80 \mu \mathrm{g} / \mathrm{L} \text { and } \\
\text { biomass dosage } 22 \times 10^{8} \mathrm{CFU}\end{array}$ & $\begin{array}{l}\text { Massoud et al., } \\
2021\end{array}$ \\
\hline
\end{tabular}

Lead: Pb, Nickel: Ni, Copper: Cu, Cadmium: Cd, Iron: Fe, Mercury: Hg. 
(Massoud et al., 2020a). Therefore, they have introduced applying S. cerevisiae as a novel and useful technology for the bioremoval of heavy metals from foodstuff (Massoud et al., 2019, 2020a)

Different treatments, such as caustic, ethanol, acidic, and heat, can enhance the biosorption of heavy metals by microorganisms. In a study by Yekta Göksungur et al. (2005), "potential of baker's yeast in bioremoval of cadmium and lead with 3 pretreatments (caustic, heat and ethanol)" was examined. Ethanol-treated yeast strains could remove the most content of metals and it can be explained by improving the availability of yeast binding sites and maybe enhancing the metals accessibility (Göksungur et al., 2005).

\section{Mechanisms of Bioremoval and Stability of Complexes (Probiotics/Starters-heavy Metal/Toxin)}

$\mathrm{AFM}_{1}$ and other toxins are accumulated in milk and dairy products because they are able to bind to milk protein components such as casein (Dyomina et al., 2017; Granados-Chinchilla, 2016; Sarlak et al., 2017). Therefore, numerous investigations have been focused on the removal of toxins using microorganisms, such as LAB (Dyomina et al., 2017; Sarlak et al., 2017).

Although the mechanism of bioremoval of toxins and heavy metals by LAB was not well known until now, it is proposed that toxins are highly linked by cell wall components of microorganisms and are not metabolically degraded (Zoghi et al., 2014). Yeast and LAB are used widely to reduce toxins and metal ions. As both viable and dead cells are capable of adsorbing toxins, it is sensible to conclude that the removal of toxins is by adhesion to the components of microorganism's cell wall relative to covalent binding, as reviewed by Shetty et al. (2006) (Shetty and Jespersen, 2006). It is indicated that mannan components of the $S$. cerevisiae cell wall play an important role in toxin binding (Devegowda et al., 1996). Generally, the cell wall proteins of S. cerevisiae are bound to $\beta$-1,3-glucans by covalent linkage by $\beta$-1,6-glucan chains (Shetty and Jespersen, 2006). Apart from this, the major part of the LAB cell is made up of peptidoglycan, which contains teichoic and lipoteichoic acids. Also, a proteinous $\mathrm{S}$-layer and neutral polysaccharides as components of the LAB cell wall have been recognized and reviewed by Lahtinen et al. (2004).

A study by Yiannikouris et al. (2004) indicated the interactions between zearalenone and $\beta$-D-glucans, in which $\beta-1,3$ D-glucan chains constitute a stable helical link with zearalenone and stabilized by $\beta-1,6 \mathrm{D}$-glucan chains (Yiannikouris et al., 2004). In order to investigate the mechanism of binding of aflatoxins to L. rhamnosus it is indicated that carbohydrates in the cell wall are predominantly responsible for binding to aflatoxins. In samples treated by urea, it is shown that hydrophobic interactions play a significant role in binding, and treatment by $\mathrm{NaCl}$ and $\mathrm{CaCl}_{2}$ showed that electrostatic interactions played a minor role (Haskard et al., 2000).

Also, it is stated that $\mathrm{AFM}_{1}$ is bound to LAB cell wall components by weak noncovalent interactions. The difference in the binding ability among different microorganisms is attributed to the cell wall and cell envelope structures (El Khoury et al., 2011). Similarly, Turbic et al. (2002) mentioned that the different binding ability of LAB highly depended on the strain of the microorganisms (Turbic et al., 2002).

Another study associated with the mechanism of biosorption illustrated that nonviable cells, including heat and acid-treated cells, produced complexes with higher stability, which means better access of groups in treated cells rather than viable ones. This phenomenon emphasizes that the viability of cells is not an important factor for the binding ability of cells (Haskard et al., 2001). Furthermore, it is shown that acids might be capable of breaking amine binding in peptides and proteins, which leads to the production of peptides and even amino acids, and consequently, more accessible aflatoxin binding sites will be available (El-Nezami et al., 2002). Similarly, it is noted that hydrophobic interactions are highly expected in LAB, which is treated by acid because acid treatment leads to denaturation of proteins and enhanced hydrophobic binding sites (Haskard et al., 2000).

Moreover, the mechanisms of bioremoval could be influenced by various factors including types of microorganisms or even the status of biomass (living or nonliving microorganism), chemical properties of toxic materials, and environmental factors, such as temperature as well as pH (Javanbakht et al., 2014).

For more illustration, Javanbakht et al. (2014) investigated the mechanism of removal of heavy metals by microorganisms. They suggested that two different types of pathways are involved in biosorption, which depends on cell metabolism and is divided into metabolism-dependent and metabolism-independent groups. The first pathway only occurs in viable cells through the transformation of metals across the cell wall. The second mechanism is involved in the physicochemical interaction between metals and functional groups of cell surface such as physical adsorption and ion exchange without depending on the cell metabolisms (Javanbakht et al., 2014).

To investigate the stability of complexes, Haskard et al. (2001) evaluated the stability of 12 complexes between 
$\mathrm{LAB}$ and $\mathrm{AFB}_{1}$ considering both viable and nonviable cells and concluded that $71 \%$ of $\mathrm{AFB}_{1}$ remained bound, indicating the high stability of the complexes. Also, they showed that nonviable cells retained a higher amount of $\mathrm{AFB}_{1}$, as mentioned above (Haskard et al., 2001). Based on their results, the stability of complexes depends upon three factors including strain, treatment type, and environmental conditions. Fazeli et al. (2009) conducted a study to investigate the effect of strains, including L. casei, L. plantarum, and L. fermentum, on the reduction of $\mathrm{AFB}_{1}$ and concluded that all the strains were able to remove $\mathrm{AFB}_{1}$, although $L$. casei was found to be a stronger binder of $\mathrm{AFB}_{1}$ rather than other bacteria (Fazeli et al., 2009).

A Study by Zoghi et al. (2020) showed that adsorption of patulin by LAB can be reversible in simulated gastrointestinal conditions. The reversibility of binding between $\mathrm{LAB}$ and patulin can be explained by the sense of noncovalent electrostatic bonds (Van der Waals and hydrogen bonds) (Zoghi et al., 2020). Similarly, in another study, the adsorption of $\mathrm{AFB}_{1}$, zearalenone, and ochratoxin A by kefir grains in simulated gastrointestinal $\mathrm{pH}$ was reversible. In $\mathrm{pH} 3$, further amounts of toxins were released (Taheur et al., 2017). Moreover, reduction of $\mathrm{AFB}_{1}$ from a gastrointestinal model by several cells, including L. rhamnosus, L. plantarum, and L. acidophilus, were examined by Motameny et al. (2012), and they concluded that L. plantarum was the most active cell (Motameny et al., 2012).

\section{Conclusions}

Aflatoxins and heavy metals frequently contaminate milk and dairy products at different levels. In the food industry, controlling aflatoxin and heavy metal levels in dairy products is a challenge for researchers. According to the recent studies summarized in this review, it is revealed that using different microorganisms (such as probiotics) in different dairy products could result in the removal of toxins and heavy metals by creating bonds between contaminants and these microorganisms. Using the starters in fermented dairy products can be helpful in the decontamination of toxins and heavy metals. According to this review, L. bulgaricus, Kefir grains, L. acidophilus, and L. rhamnosus could be useful for decreasing $\mathrm{AFM}_{1}$ and other toxins in milk and dairy products. Also, for decontamination of heavy metals, kefir grains had the best ability for the bioremoval of different metals.

\section{Future directions}

More investigations are needed regarding the stability of binding between probiotics and toxins/heavy metals in in vivo and in vitro conditions. Also, more experiments should be done for finding optimum conditions for special starters in special dairy products for better decontamination.

\section{Declarations}

\section{Funding}

This research did not receive any specific grant from funding agencies in the public, commercial, or not-forprofit sectors.

\section{Conflicts of interest/Competing interests}

The authors declare that they have no conflicts of interest.

\section{Availability of data and material}

Not applicable.

\section{Code availability}

Not applicable.

\section{Authors' Contributions}

RM was involved in writing and original draft preparation; AZ was responsible for writing, review, and editing; KKD was concerned with conceptualization and supervision; FM was involved in writing and editing; and SJ, RM, and YR were responsible for review and editing.

\section{References}

Abdelmotilib, N.M., Hamad, G.M., Elderea, H.B., Salem, E.G. and El Sohaimy, S.A., 2018. Aflatoxin M1 reduction in milk by a novel combination of probiotic bacterial and yeast strains. European Journal of Nutrition \& Food Safety 8(2):83-99. https://doi. org/10.9734/EJNFS/2018/39486

Abedi, A.-S., Nasseri, E., Esfarjani, F., Mohammadi-Nasrabadi, F., Moosavi, M.H. and Hoseini, H., 2020. A systematic review and meta-analysis of lead and cadmium concentrations in cow milk in Iran and human health risk assessment. Environmental Science and Pollution Research 27: 10147-10159. https://doi. org/10.1007/s11356-020-07989-w

Adibpour, N., Soleimanian-Zad, S., Sarabi-Jamab, M. and Tajalli, F., 2016. Effect of storage time and concentration of aflatoxin $\mathrm{m} 1$ on toxin binding capacity of $\mathrm{L}$. acidophilus in fermented milk product. Journal of Agricultural Science and Technology 18: 1209-1220. Available from: http://jast.modares.ac.ir/article-23-44.62-en.html 
Alani, M.S. and Al-Azzawi, M.N., 2015. Assessment of lead, cadmium and copper concentrations in raw milk collected from different location in Iraq. Iraqi Journal of Science 56: 350-355.

Alkorta, I., Hernández-Allica, J., Becerril, J., Amezaga, I., Albizu, I. and Garbisu, C., 2004. Recent findings on the phytoremediation of soils contaminated with environmentally toxic heavy metals and metalloids such as zinc, cadmium, lead, and arsenic. Reviews in Environmental Science and Biotechnology 3: 71-90. https://doi.org/10.1023/B:RESB.0000040059.70899.3d

Ansari, F., Khodaiyan, F., Rezaei, K. and Rahmani, A., 2015. Modelling of aflatoxin G1 reduction by kefir grain using response surface methodology. Journal of Environmental Health Science and Engineering 13: 40. https://doi.org/10.1186/ s40201-015-0190-2

Asati, A., Pichhode, M. and Nikhil, K., 2016. Effect of heavy metals on plants: an overview. International Journal of Application or Innovation in Engineering \& Management 5: 56-66.

Aslam, N., Tipu, M.Y., Ishaq, M., Cowling, A., McGill, D., Warriach, H.M., et al. 2016. Higher levels of aflatoxin M1 contamination and poorer composition of milk supplied by informal milk marketing chains in Pakistan. Toxins 8: 347. https:// doi.org/10.3390/toxins8120347

Bervis, N., Lorán, S., Juan, T., Carramiñana, J.J., Herrera, A., Ariño, A., et al. 2021. Field monitoring of aflatoxins in feed and milk of high-yielding dairy cows under two feeding systems. Toxins 13: 201. https://doi.org/10.3390/toxins13030201

Bilandžić, N., Božić, Đ., Đokić, M., Sedak, M., Kolanović, B.S., Varenina, I., et al. 2014. Assessment of aflatoxin M1 contamination in the milk of four dairy species in Croatia. Food Control 43: 18-21. https://doi.org/10.1016/j.foodcont.2014.02.044.

Bilandžić, N., Tanković, S., Jelušić, V., Varenina, I., Kolanović, B.S., Luburić, Đ.B., et al. 2016. Aflatoxin M1 in raw and UHT cow milk collected in Bosnia and Herzegovina and Croatia. Food Control 68: 352-357. https://doi.org/10.1016/j.foodcont.2016.04.022

Bokulich, N.A., Amiranashvili, L., Chitchyan, K., Ghazanchyan, N., Darbinyan, K., Gagelidze, N., et al. 2015. Microbial biogeography of the transnational fermented milk matsoni. Food Microbiology 50: 12-19. https://doi.org/10.1016/j.fm.2015.01.018

Bovo, F., Franco, L.T., Rosim, R.E. and Oliveira, C.A.F.D., 2014. Ability of a Lactobacillus rhamnosus strain cultured in milk whey based medium to bind aflatoxin B1. Food Science and Technology 34: 566-570. https://doi.org/10.1590/1678-457x.6373

Camaj, A., Meyer, K., Berisha, B., Arbneshi, T. and Haziri, A., 2018. Aflatoxin M 1 contamination of raw cow's milk in five regions of Kosovo during 2016. Mycotoxin Research 34: 205-209. https:// doi.org/10.1007/s12550-018-0315-4.

Campagnollo, F.B., Khaneghah, A.M., Borges, L.L., Bonato, M.A., Fakhri, Y., Barbalho, C.B., et al. 2020. In vitro and in vivo capacity of yeast-based products to bind to aflatoxins B1 and M1 in media and foodstuffs: a systematic review and meta-analysis. Food Research International 137: 109505. https://doi. org/10.1016/j.foodres.2020.109505

Castro-González, N.P., Calderón-Sánchez, F., Castro de Jesús, J., Moreno-Rojas, R., Tamariz-Flores, J.V., Pérez-Sato, M., et al. 2018. Heavy metals in cow's milk and cheese produced in areas irrigated with waste water in Puebla, Mexico. Food Additives \&
Contaminants: Part B 11: 33-36. https://doi.org/10.1080/19393 210.2017.1397060

Cherni, Y., Botta, C., Kasmi, M., Franciosa, I., Cocolin, L., Chatti, A., et al. 2020. Mixed culture of Lactococcus lactis and Kluyveromyces marxianus isolated from kefir grains for pollutants load removal from Jebel Chakir Leachate. Water Environment Research, 92, 2041-2048. https://doi.org/10.1002/wer.1363

Commission, E., 2006. Commission Regulation (EC) No 1881/2006 of 19 December 2006 setting maximum levels for certain contaminants in foodstuffs. Official Journal of the European Union 364: 5-24.

Corassin, C., Bovo, F., Rosim, R. and Oliveira, C., 2013. Efficiency of Saccharomyces cerevisiae and lactic acid bacteria strains to bind aflatoxin M1 in UHT skim milk. Food Control 31: 80-83. https://doi.org/10.1016/j.foodcont.2012.09.033

de Oliveira, T.M., Peres, J.A., Felsner, M.L. and Justi, K.C., 2017. Direct determination of $\mathrm{Pb}$ in raw milk by graphite furnace atomic absorption spectrometry (GF AAS) with electrothermal atomization sampling from slurries. Food Chemistry 229: 721725. https://doi.org/10.1016/j.foodchem.2017.02.143

De Roma, A., Rossini, C., Ritieni, A., Gallo, P. and Esposito, M., 2017. A survey on the Aflatoxin M1 occurrence and seasonal variation in buffalo and cow milk from Southern Italy. Food Control 81: 30-33. https://doi.org/10.1016/j.foodcont.2017.05.034

Devegowda, G., Aravind, B. and Morton, M., 1996. Saccharomyces cerevisiae and mannanoligosaccharides to counteract aflatoxicosis in broilers. Proceedings of Australian Poultry Science Symposium, Sydney. pp. 106.

Dimitrieska-Stojković, E., Stojanovska-Dimzoska, B., Ilievska, G., Uzunov, R., Stojković, G., Hajrulai-Musliu, Z., et al. 2016. Assessment of aflatoxin contamination in raw milk and feed in Macedonia during 2013. Food Control 59: 201-206. https://doi. org/10.1016/j.foodcont.2015.05.019

Dyomina, M., Goroz, Y.O., Kalyuzhnaya, O. and Strelnikov, L., 2017. Technology of preparation of homemade fermented milk products and study their microflora. National University of Pharmacy, Kharkiv, Ukraine

Eker, F.Y., Muratoglu, K. and Eser, A.G., 2019. Detection of aflatoxin M 1 in milk and milk products in Turkey. Environmental Monitoring and Assessment 191: 1-8. https://doi.org/10.1007/ s10661-019-7668-9

El Khoury, A., Atoui, A. and Yaghi, J., 2011. Analysis of aflatoxin M1 in milk and yogurt and AFM1 reduction by lactic acid bacteria used in Lebanese industry. Food Control 22: 1695-1699. https:// doi.org/10.1016/j.foodcont.2011.04.001

El-Nezami, H., Polychronaki, N., Salminen, S. and Mykkänen, H., 2002. Binding rather than metabolism may explain the interaction of two food-grade Lactobacillus strains with zearalenone and its derivative $\alpha$-Zearalenol. Applied and Environmental Microbiology 68: 3545-3549. https://doi.org/10.1128/AEM.68.7. 3545-3549.2002

El Sheikha, A., 2015. Food safety issues in Saudi Arabia. Nutrition and Food Technology 1: 1-4. https://doi.org/10.16966/2470-6086.103

El Sheikha, A.F., 2019. Molecular detection of mycotoxigenic fungi in foods: the case for using PCR-DGGE. Food Biotechnology 33: 54-108. https://doi.org/10.1080/08905436.2018.1547644 
El Sheikha, A.F., Levin, R.E. and Xu, J., 2018. Molecular techniques in food biology: safety, biotechnology, authenticity and traceability. John Wiley \& Sons.

El Sheikha, A.F. and Montet, D., 2014. African fermented foods: historical roots and real benefits. Microorganisms and fermentation of traditional foods. CRC Press, Taylor and Francis Group, Boca Raton, FL, pp. 248-282.

Elsanhoty, R.M., Salam, S.A., Ramadan, M.F. and Badr, F.H., 2014. Detoxification of aflatoxin M1 in yoghurt using probiotics and lactic acid bacteria. Food Control 43: 129-134. https://doi. org/10.1016/j.foodcont.2014.03.002

Fallah, A.A., Barani, A. and Nasiri, Z., 2015. Aflatoxin M1 in raw milk in Qazvin Province, Iran: a seasonal study. Food Additives \& Contaminants: Part B 8: 195-198. https://doi.org/1 0.1080/19393210.2015.1046193

FAO/WHO, 2001. Evaluation of health and nutritional properties of powder milk and live lactic acid bacteria, pp. 1-4.

Fazeli, M.R., Hajimohammadali, M., Moshkani, A., Samadi, N., Jamalifar, H., Khoshayand, M.R., et al. 2009. Aflatoxin B1 binding capacity of autochthonous strains of lactic acid bacteria. Journal of Food Protection 72: 189-192. https://doi. org/10.4315/0362-028X-72.1.189

Ferreira, A. and Viljoen, B., 2003. Yeasts as adjunct starters in matured Cheddar cheese. International Journal of Food Microbiology 86: 131-140. https://doi.org/10.1016/S01681605(03)00252-6

Fguiri, I., Ziadi, M., Abassi, M., Arroum, S. and Khorchani, T., 2013. Suitability of camel milk to transformation in Leben by lactic starter. African Journal of Microbiology Research 6: 7185-7192.

Foroughi, M., Sarabi Jamab, M., Keramat, J. and Foroughi, M., 2018. Immobilization of Saccharomyces cerevisiae on Perlite Beads for the Decontamination of Aflatoxin M1 in Milk. Journal of Food Science 83: 2008-2013. https://doi.org/10.1111/1750-3841.14100

Garrote, G.L., Abraham, A.G. and De Antoni, G.L., 2001. Chemical and microbiological characterisation of kefir grains. The Journal of Dairy Research 68: 639. https://doi.org/10.1017/ S0022029901005210

Giovati, L., Magliani, W., Ciociola, T., Santinoli, C., Conti, S. and Polonelli, L., 2015. AFM1 in milk: physical, biological, and prophylactic methods to mitigate contamination. Toxins 7: 43304349. https://doi.org/10.3390/toxins7104330

Göksungur, Y., Üren, S. and Güvenç, U., 2005. Biosorption of cadmium and lead ions by ethanol treated waste baker's yeast biomass. Bioresource Technology 96: 103-109. https://doi. org/10.1016/j.biortech.2003.04.002

Gonçalves B.L., Uliana R.D., Coppa C.F.S.C., In Lee S.H., Kamimura E.S., Oliveira C.A.F., et al. (2020) Aflatoxin M1: biological decontamination methods in milk and cheese. Food Science and Technology [online]. 2020 [Accessed 18 June 2021]. Available from: https://doi.org/10.1590/fst.22920

Granados-Chinchilla, Fabio., 2016. Insights into the interaction of milk and dairy proteins with aflatoxin $\mathrm{m} 1$. In: Isabel, G. (ed.) Milk proteins-from structure to biological properties and health aspects, pp. 265-286.

Gupta, R., Bimlesh, M., Joshi, V. and Prasad, D., 2000. Microbiological, chemical and ultrastructural characteristics of Mishti Doi (Sweetened Dahi). Journal of Food Science and Technology (Mysore) 37: 54-57.

Hadiani, M.R., Darani, K.K., Rahimifard, N. and Younesi, H., 2018. Biosorption of low concentration levels of Lead (II) and Cadmium (II) from aqueous solution by Saccharomyces cerevisiae: response surface methodology. Biocatalysis and Agricultural Biotechnology 15: 25-34. https://doi.org/10.1016/j. bcab.2018.05.001

Hadiani, M.R., Khosravi-Darani, K. and Rahimifard, N., 2019. Optimization of As (III) and As (V) removal by Saccharomyces cerevisiae biomass for biosorption of critical levels in the food and water resources. Journal of Environmental Chemical Engineering 7: 102949. https://doi.org/10.1016/j.jece.2019.10294.9

Halagarda, M., Ptasinska-Marcinkiewicz, J. and Fijorek, K., 2018. A comparison of mineral elements content in conventional and organic milk from Southern Poland. Żywność Nauka Technologia Jakość 25: 137-150.

Hashim, M. and Chu, K., 2004. Biosorption of cadmium by brown, green, and red seaweeds. Chemical Engineering Journal 97: 249-255. https://doi.org/10.1016/S1385-8947(03)00216-X

Haskard, C., Binnion, C. and Ahokas, J., 2000. Factors affecting the sequestration of aflatoxin by Lactobacillusrhamnosus strain GG. Chemico-Biological Interactions 128: 39-49. https://doi. org/10.1016/S0009-2797(00)00186-1

Haskard, C.A., El-Nezami, H.S., Kankaanpää, P.E., Salminen, S. and Ahokas, J.T., 2001. Surface binding of aflatoxin B1 by lactic acid bacteria. Applied and Environmental Microbiology 67: 30863091. https://doi.org/10.1128/AEM.67.7.3086-3091.2001

Hayat, K., Menhas, S., Bundschuh, J. and Chaudhary, H.J., 2017. Microbial biotechnology as an emerging industrial wastewater treatment process for arsenic mitigation: a critical review. Journal of Cleaner Production 151: 427-438. https://doi. org/10.1016/j.jclepro.2017.03.084

Huang, L., Zheng, N., Zheng, B., Wen, F., Cheng, J., Han, R., et al. 2014. Simultaneous determination of aflatoxin M1, ochratoxin A, zearalenone and $\alpha$-zearalenol in milk by UHPLC-MS/ MS. Food Chemistry 146: 242-249. https://doi.org/10.1016/j. foodchem.2013.09.047

Iha, M.H., Barbosa, C.B., Okada, I.A. and Trucksess, M.W., 2013. Aflatoxin M1 in milk and distribution and stability of aflatoxin M1 during production and storage of yoghurt and cheese. Food Control 29: 1-6. https://doi.org/10.1016/j.foodcont.2012. 05.058

Ismail, A., Levin, R.E., Riaz, M., Akhtar, S., Gong, Y.Y. and de Oliveira, C.A., 2017. Effect of different microbial concentrations on binding of aflatoxin M1 and stability testing. Food Control 73: 492-496. https://doi.org/10.1016/j.foodcont.2016.08.040

Ismail, A., Riaz, M., Akhtar, S., Ismail, T., Ahmad, Z. and Hashmi, M.S., 2015. Estimated daily intake and health risk of heavy metals by consumption of milk. Food Additives \& Contaminants: Part B 8: 260-265. https://doi.org/10.1080/19393210.2015. 1081989

Javanbakht, V., Alavi, S.A. and Zilouei, H., 2014. Mechanisms of heavy metal removal using microorganisms as biosorbent. Water Science and Technology 69: 1775-1787. https://doi. org/10.2166/wst.2013.718 
Kamyar, S. and Movassaghghazani, M., 2017. Reduction of Aflatoxin M1 in milk using Kefir Starter. Iranian Journal of Toxicology 11: 27-31. https://doi.org/10.29252/arakmu.11.6.27

Karazhiyan, H., Mehraban, S.M., Karazhyan, R., Mehrzad, A. and Haghighi, E., 2016. Ability of different treatments of Saccharomyces cerevisiae to surface bind aflatoxin M1 in yoghurt. Journal of Agricultural science and Technology, 18:1489-1498.

Karczmarczyk, A., Baeumner, A.J. and Feller, K.-H., 2017. Rapid and sensitive inhibition-based assay for the electrochemical detection of Ochratoxin A and Aflatoxin M1 in red wine and milk. Electrochimica Acta 243: 82-89. https://doi.org/10.1016/j. electacta.2017.05.04.6

Khairul, I., Wang, Q.Q., Jiang, Y.H., Wang, C. and Naranmandura, H., 2017. Metabolism, toxicity and anticancer activities of arsenic compounds. Oncotarget 8: 23905. https://doi.org/10.18632/ oncotarget.14733

Khosravi-Darani, K., Barzegar, F. and Baghdadi, M., 2019. Detoxification of heterocyclic aromatic amines by probiotic to inhibit medical hazards. Mini Reviews in Medicinal Chemistry 19: 1196-1203. https://doi.org/10.2174/1389557519666190318102201

Kos, J., Lević, J., Đuragić, O., Kokić, B. and Miladinović, I., 2014. Occurrence and estimation of aflatoxin M1 exposure in milk in Serbia. Food Control 38: 41-46. https://doi.org/10.1016/j. foodcont.2013.09.060

Kuboka, M.M., Imungi, J.K., Njue, L., Mutua, F., Grace, D. and Lindahl, J.F., 2019. Occurrence of aflatoxin M1 in raw milk traded in peri-urban Nairobi, and the effect of boiling and fermentation. Infection Ecology \& Epidemiology 9: 1625703. https://doi.org/10.1080/20008686.2019.1625703

Kumar, R., Kaur, M., Garsa, A.K., Shrivastava, B., Reddy, V. and Tyagi, A., 2015. Natural and cultured buttermilk. In: Fermented milk and dairy products, pp. 203-225.

Lahtinen, S., Haskard, C., Ouwehand, A., Salminen, S. and Ahokas, J., 2004. Binding of aflatoxin B1 to cell wall components of Lactobacillus rhamnosus strain GG. Food Additives and Contaminants 21: 158-164. https://doi.org/10.1080/026520303 10001639521

Macori, G. and Cotter, P.D., 2018. Novel insights into the microbiology of fermented dairy foods. Current Opinion in Biotechnology 49: 172-178. https://doi.org/10.1016/j.copbio.2017.09.002

Malhat, F., Hagag, M. and Saber, A., 2012. Contamination of cows milk by heavy metal in Egypt. Bulletin of Environmental Contamination and Toxicology 88: 611-613. https://doi. org/10.1007/s00128-012-0550-x

Mannani, N., Tabarani, A., El Adlouni, C. and Zinedine, A., 2021. Aflatoxin M1 in pasteurized and UHT milk marked in Morocco. Food Control 124: 107893. https://doi.org/10.1016/j. foodcont.2021.107893

Masoud, R., Khosravi-Darani, K., Sharifan, A., Asadi, G.-H. and Younesi, H., 2020. The biosorption capacity of Saccharomyces cerevisiae for cadmium in milk.

Massoud, R., Cruz, A. and Darani, K.K., 2018. Ochratoxin A: from safety aspects to prevention and remediation strategies. Current Nutrition \& Food Science 14: 11-16. https://doi.org/10.2174/15 73401313666170517165500
Massoud, R., Khosravi-Darani, K., Sharifan, A. and Asadi, G.H., 2019. Lead bioremoval from milk by Saccharomyces cerevisiae. Biocatalysis and Agricultural Biotechnology 22: 101437. https:// doi.org/10.1016/j.bcab.2019.101437

Massoud, R., Khosravi-Darani, K., Sharifan, A., Asadi, G.H. and Younesi, H., 2020a. The biosorption capacity of Saccharomyces cerevisiae for cadmium in milk. Dairy (journal) 1: 169-176. https://doi.org/10.3390/dairy1020011

Massoud, R., Khosravi-Darani, K., Sharifan, A., Asadi, G. and Zoghi, A., 2020b. Lead and cadmium biosorption from milk by Lactobacillus acidophilus ATCC 4356. Food Science \& Nutrition 8: 5284-5291. https://doi.org/10.1002/fsn3.1825

Massoud, R., Sharifan, A., Khosravi-Darani, K. and Asadi, G., 2021. Mercury biosorption process by using Saccharomyces cerevisiae in milk. Journal of Food Processing and Preservation 45: e15008. https://doi.org/10.1111/jfpp.15008

Meshref, A.M., Moselhy, W.A. and Hassan, N.E.-H.Y., 2014. Heavy metals and trace elements levels in milk and milk products. Journal of Food Measurement and Characterization 8: 381-388. https://doi.org/10.1007/s11694-014-9203-6

Michlig, N., Signorini, M., Gaggiotti, M., Chiericatti, C., Basílico, J.C., Repetti, M.R. and Beldoménico, H.R., 2016. Risk factors associated with the presence of aflatoxin $\mathrm{M} 1$ in raw bulk milk from Argentina. Food Control 64: 151-156. https://doi. org/10.1016/j.foodcont.2015.12.025

Milanowski, M., Pomastowski, P., Railean-Plugaru, V., Rafińska, K., Ligor, T. and Buszewski, B., 2017. Biosorption of silver cations onto Lactococcus lactis and Lactobacillus casei isolated from dairy products. PLoS One 12: e0174521. https://doi. org/10.1371/journal.pone.0174521

Miura, N., Yoshioka, H., Ashimori, A., Ohtani, K., Hasegawa, T., Hwang, G.-W., Ikeda, M. and Nonogaki, T., 2017. Multidirectional analyses of hepatic chronotoxicity induced by cadmium in mice. The Journal of Toxicological Sciences 42 : 597-604. https://doi.org/10.2131/jts.42.597

Motameny, R., Sadeghi, A., Dehghan-Banadaky, M., Chamani, M. and Abolhassani, M., 2012. Effect of some acid treated bacteria on reduction of impure aflatoxin B1 in ruminant gastrointestinal model. The Journal of American Science 8: 213-217.

Muhib, M.I., Chowdhury, M.A.Z., Easha, N.J., Rahman, M.M., Shammi, M., Fardous, Z., et al. 2016. Investigation of heavy metal contents in cow milk samples from area of Dhaka, Bangladesh. International Journal of Food Contamination 3: 1-10. https://doi.org/10.1186/s40550-016-0039-1

Naidoo, S.V.K., Bester, M.J., Arbi, S., Venter, C., Dhanraj, P. and Oberholzer, H.M., 2019. Oral exposure to cadmium and mercury alone and in combination causes damage to the lung tissue of Sprague-Dawley rats. Environmental Toxicology and Pharmacology 69: 86-94. https://doi.org/10.1016/j.etap.2019.03.021

Njombwa, C.A., Moreira, V., Williams, C., Aryana, K. and Matumba, L., 2021. Aflatoxin M 1 in raw cow milk and associated hepatocellular carcinoma risk among dairy farming households in Malawi. Mycotoxin Research 37: 89-96. https://doi. org/10.1007/s12550-020-00417-5

Patterson,W James. and Minear, Roger., 2013. Physical-chemical methods of heavy metals removal. In: Heavy metals in the 
aquatic environment. Elsevier, Amsterdam, the Netherlands, pp. 261-276. https://doi.org/10.1016/B978-0-08-018068-7.50040-X Peña-Rodas, O., Martinez-Lopez, R. and Hernandez-Rauda, R., 2018. Occurrence of Aflatoxin M1 in cow milk in El Salvador: results from a two-year survey. Toxicology Reports 5: 671-678. https://doi.org/10.1016/j.toxrep.2018.06.004.

Porova, N., Botvinnikova, V., Krasulya, O., Cherepanov, P. and Potoroko, I., 2014. Effect of ultrasonic treatment on heavy metal decontamination in milk. Ultrasonics Sonochemistry 21: 21072111. https://doi.org/10.1016/j.ultsonch.2014.03.029

Poulsen, P., 1970. Ymer', a Danish protein-enriched fermented milk-product. XVIII International Dairy Congress, Sydney.

Puga-Torres, B., Salazar, D., Cachiguango, M., Cisneros, G. and Gómez-Bravo, C., 2020. Determination of aflatoxin M1 in raw milk from different provinces of Ecuador. Toxins 12: 498. https:// doi.org/10.3390/toxins12080498

Raftaniamiri, Z., Khandelwal, P. and Aruna, B.R., 2010. Development of acidophilus milk via selected probiotics \&amp;amp; prebiotics using artificial neural network. Advances in Bioscience and Biotechnology 1(3): 4. https://doi.org/10.4236/abb.2010.13031

Ray C Ramesh., El Sheikha, Aly F. and Kumar, Sasi. 2014. Oriental fermented functional (probiotic) foods. In: Microorganisms and fermentation of traditional foods. Food biology series. Science Publishers Inc., Boca Raton, FL, pp. 283-311.

Redzwan, S.M., Abd Mutalib, M.S., Wang, J.-S., Ahmad, Z., Kang, M.-S., Nasrabadi, E.N., et al. 2016. Effect of supplementation of fermented milk drink containing probiotic Lactobacillus casei Shirota on the concentrations of aflatoxin biomarkers among employees of Universiti Putra Malaysia: a randomised, double-blind, cross-over, placebo-controlled study. British Journal of Nutrition 115: 39-54. https://doi.org/10.1017/ S0007114515004109

Rodríguez-Blanco, M., Ramos, A., Prim, M., Sanchis, V. and Marín, S., 2020. Usefulness of the analytical control of aflatoxins in feedstuffs for dairy cows for the prevention of aflatoxin M 1 in milk. Mycotoxin Research 36: 11-22. https://doi.org/10.1007/ s12550-019-00362-y

Ryan, P., Ross, R., Fitzgerald, G., Caplice, N. and Stanton, C., 2015. Sugar-coated: exopolysaccharide producing lactic acid bacteria for food and human health applications. Food \& Function 6: 679-693. https://doi.org/10.1039/C4FO00529E

Salque, M., Bogucki, P.I., Pyzel, J., Sobkowiak-Tabaka, I., Grygiel, R., Szmyt, M. and Evershed, R.P., 2013. Earliest evidence for cheese making in the sixth millennium BC in northern Europe. Nature 493: 522-525. https://doi.org/10.1038/nature11698

Sanders, M.E., Lenoir-Wijnkoop, I., Salminen, S., Merenstein, D.J., Gibson, G.R., Petschow, B.W., et al. 2014. Probiotics and prebiotics: prospects for public health and nutritional recommendations. Annals of the New York Academy of Sciences 1309: 19-29. https://doi.org/10.1111/nyas.12377

Sani, A.M., Marhamati, Z., and Marhamatizade, M., 2014. Biodetoxification of aflatoxin M1 in kefir using Lactobacillus casei. Biotechnology: An Indian Journal 9: 219-224.

Sarimehmetoğlu, B. and Küplülü, Ö., 2004. Binding ability of aflatoxin M1 to yoghurt bacteria. Ankara Üniv Vet Fak Derg, 51: 195-198.
Sarlak, Z., Rouhi, M., Mohammadi, R., Khaksar, R., Mortazavian, A.M., Sohrabvandi, S. and Garavand, F., 2017. Probiotic biological strategies to decontaminate aflatoxin M1 in a traditional Iranian fermented milk drink (Doogh). Food Control 71: 152-159. https://doi.org/10.1016/j.foodcont.2016.06.037

Sarlak, Z.A.K.K.-D., 2020. Probiotics: the last trench for environmental pollution of organophosphorus pesticides. Journal of Health Sciences and Enviornments. submitted, revised.

Satyapal, G., Rani, S., Kumar, M. and Kumar, N., 2016. Potential role of arsenic resistant bacteria in bioremediation: current status and future prospects. Journal of Microbial and Biochemical Technology 8: 256-258. https://doi. org/10.4172/1948-5948.1000294

Seğmenoğlu, M.S. and Baydan, E., 2021. Comparison of heavy metal levels of organic and conventional milk and milk products in Turkey. Turkish Journal of Agriculture-Food Science and Technology 9: 696-700. https://doi.org/10.24925/turjaf. v9i4.696-700.4007

Sevim, S., Topal, G.G., Tengilimoglu-Metin, M.M., Sancak, B. and Kizil, M., 2019. Effects of inulin and lactic acid bacteria strains on aflatoxin M1 detoxification in yoghurt. Food Control 100: 235-239. https://doi.org/10.1016/j.foodcont.2019.01.028

Shahbazi, Y., Ahmadi, F. and Fakhari, F., 2016. Voltammetric determination of $\mathrm{Pb}, \mathrm{Cd}, \mathrm{Zn}, \mathrm{Cu}$ and $\mathrm{Se}$ in milk and dairy products collected from Iran: an emphasis on permissible limits and risk assessment of exposure to heavy metals. Food Chemistry 192: 1060-1067. https://doi.org/10.1016/j.foodchem.2015.07.123

Sharma, H., Jadhav, V.J. and Garg, S.R., 2020. Aflatoxin M1 in milk in Hisar city, Haryana, India and risk assessment. Food Additives \& Contaminants: Part B 13: 59-63. https://doi.org/10.1080/193 93210.2019.1693434

Shetty, P.H. and Jespersen, L., 2006. Saccharomyces cerevisiae and lactic acid bacteria as potential mycotoxin decontaminating agents. Trends in Food Science \& Technology 17: 48-55. https:// doi.org/10.1016/j.tifs.2005.10.004

Shigute, T. and Washe, A.P., 2018. Reduction of aflatoxin M1 levels during ethiopian traditional fermented milk (Ergo) production. Journal of Food Quality 2018, pp. 10. https://doi. org/10.1155/2018/4570238

Shuib, N.S., Makahleh, A., Salhimi, S.M. and Saad, B., 2017. Natural occurrence of aflatoxin M1 in fresh cow milk and human milk in Penang, Malaysia. Food Control 73: 966-970. https://doi. org/10.1016/j.foodcont.2016.10.013

Simova, E., Beshkova, D., Angelov, A., Hristozova, T., Frengova, G. and Spasov, Z., 2002. Lactic acid bacteria and yeasts in kefir grains and kefir made from them. Journal of Industrial Microbiology and Biotechnology 28: 1-6. https://doi. org/10.1038/sj/jim/7000186

Sulaymon, A.H., Mohammed, A.A. and Al-Musawi, T.J., 2013. Competitive biosorption of lead, cadmium, copper, and arsenic ions using algae. Environmental Science and Pollution Research 20: 3011-3023. https://doi.org/10.1007/s11356-012-1208-2

Suturović, Z., Kravić, S., Milanović, S., Đurović, A. and Brezo, T., 2014. Determination of heavy metals in milk and fermented milk products by potentiometric stripping analysis with constant 
inverse current in the analytical step. Food Chemistry 155: 120 125. https://doi.org/10.1016/j.foodchem.2014.01.030

Taheur, F.B., Fedhila, K., Chaieb, K., Kouidhi, B., Bakhrouf, A. and Abrunhosa, L., 2017. Adsorption of aflatoxin B1, zearalenone and ochratoxin A by microorganisms isolated from Kefir grains. International Journal of Food Microbiology 251: 1-7. https:// doi.org/10.1016/j.ijfoodmicro.2017.03.021

Tamime, A., Muir, D., Khaskheli, M. and Barclay, M., 2000. Effect of processing conditions and raw materials on the properties of Kishk 1. Compositional and microbiological qualities. LWT-Food Science and Technology 33: 444-451. https://doi. org/10.1006/fstl.2000.0686

Turbic, A., Ahokas, J. and Haskard, C., 2002. Selective in vitro binding of dietary mutagens, individually or in combination, by lactic acid bacteria. Food Additives \& Contaminants 19: 144-152. https://doi.org/10.1080/02652030110070067

U.S. Food and Drug Administration, 2019. Levels for aflatoxins in animal food, compliance policy guide. Available at: https://www. fda.gov/media/121202/download (accessed on 16 July 2019).

Venâncio, R.L., Ludovico, A., de Santana, E.H.W., de Toledo, E.A., de Almeida Rego, F.C. and Dos Santos, J.S., 2019. Occurrence and seasonality of aflatoxin M1 in milk in two different climate zones. Journal of the Science of Food and Agriculture 99: 32033206. https://doi.org/10.1002/jsfa.9487

Vishnoi, N., Dixit, S. and Singh, D., 2014. Surface binding and intracellular uptake of arsenic in bacteria isolated from arsenic contaminated site. Ecological Engineering 73: 569-578. https://doi. org/10.1016/j.ecoleng.2014.09.090

Wochner, K.F., Becker-Algeri, T.A., Colla, E., Badiale-Furlong, E. and Drunkler, D.A., 2018. The action of probiotic microorganisms on chemical contaminants in milk. Critical Reviews in Microbiology 44: 112-123. https://doi.org/10.1080/10408 41X.2017.1329275

Yadav, H., Jain, S. and Sinha, P., 2005. Preparation of low fat probiotic dahi. Journal of Dairying, Foods and Home Sciences 24: 172-177.

Yang, Q., Li, Z., Lu, X., Duan, Q., Huang, L. and Bi, J., 2018. A review of soil heavy metal pollution from industrial and agricultural regions in China: pollution and risk assessment. Science of the Total Environment 642: 690-700. https://doi.org/10.1016/j. scitotenv.2018.06.068

Yerlikaya, O., 2014. Starter cultures used in probiotic dairy product preparation and popular probiotic dairy drinks. Food Science and Technology 34: 221-229. https://doi.org/10.1590/ fst.2014.0050
Yiannikouris, A., André, G., Buléon, A., Jeminet, G., Canet, I., François, J., Bertin, G. and Jouany, J.-P., 2004. Comprehensive conformational study of key interactions involved in zearalenone complexation with $\beta$-D-glucans. Biomacromolecules 5: 2176-2185. https://doi.org/10.1021/bm049775g

Yu, B., Chang, C.-H. and Lee, T.-T., 2015. Effects of the probiotics supplementation in diet on intestinal microflora ecosystem in broilers. Journal of Advanced Agricultural Technologies, 2: 138142. https://doi.org/10.12720/joaat.2.2.138-142

Zakaria, A.M., Amin, Y.A., Khalil, O.S.F., Abdelhiee, E.Y. and Elkamshishi, M.M., 2019. Rapid detection of aflatoxin M1 residues in market milk in Aswan Province, Egypt and effect of probiotics on its residues concentration. Journal of Advanced Veterinary and Animal Research 6: 197. https://doi.org/10.5455/ javar.2019.f332

Zeynab, R., Pratima, K. and Aruna, B.R., 2010. Development of acidophilus milk via selected probiotics \& prebiotics using artificial neural network. Advances in Bioscience and Biotechnology, 1: 224-231. https://doi.org/10.4236/abb.2010.13031

Zhang, W.-L., Du, Y., Zhai, M.-M. and Shang, Q., 2014. Cadmium exposure and its health effects: a 19-year follow-up study of a polluted area in China. Science of the Total Environment 470: 224-228. https://doi.org/10.1016/j.scitotenv.2013.09.070

Ziarati, P., Shirkhan, F., Mostafidi, M. and Zahedi, M.T., 2018. An overview of the heavy metal contamination in milk and dairy products. Acta Scientific Pharmaceutical Sciences 2: 1-14.

Zoghi, A., Khosravi-Darani, K. and Sohrabvandi, S., 2014. Surface binding of toxins and heavy metals by probiotics. Mini Reviews in Medicinal Chemistry 14: 84-98. https://doi.org/10.2174/1389 557513666131211105554

Zoghi, A., Khosravi-Darani, K., Sohrabvandi, S. and Attar, H., 2019. Patulin removal from synbiotic apple juice using Lactobacillus plantarum ATCC 8014. Journal of Applied Microbiology 126: 1149-1160. https://doi.org/10.1111/jam.14172

Zoghi, A., Khosravi-Darani, K., Sohrabvandi, S., Attar, H. and Alavi, S.A., 2017. Effect of probiotics on patulin removal from synbiotic apple juice. Journal of the Science of Food and Agriculture 97: 2601-2609. https://doi.org/10.1002/jsfa.8082

Zoghi, A., Khosravi Darani, K. and Hekmatdoost, A., 2020. Effects of pretreatments on patulin removal from apple juices using Lactobacilli: binding stability in simulated gastrointestinal condition and modeling. Probiotics and Antimicrobial Proteins 1-11. https://doi.org/10.1007/s12602-020-09666-3 